\title{
Practice recommendations for clinicians in ART centers in the context of COVID-19 pandemic: perspective of a developing country
}

\author{
Tarek A. Farghaly ${ }^{1}$, Mohamed Fawzy ${ }^{2}$ and Ahmed M. Abbas ${ }^{1,3^{*}}$ (D)
}

In December 2019, severe acute respiratory syndrome coronavirus 2 (SARS-CoV-2) firstly presented in a group of patients suffering from symptoms of pneumonia in Wuhan, China [1]. The disease caused by SARS-CoV-2 is coronavirus disease-2019 (COVID-19) that was considered as a worldwide pandemic by the World Health Organization, with more than 4,000,000 cases globally $[2,3]$.

In Egypt, in vitro fertilization (IVF) is a client-paid service with no medical insurance, the cost of IVF cycles is high relative to the average yearly income of Egyptians, and private centers mainly offer assisted reproduction services. Therefore, pragmatic solutions should be established to amend the recent guidelines to suit the local requirements in the context of the golden rule of "do no harm." These solutions should be in conjunction with the latest guidelines to continue the proper management of patients while ensuring adequate resource allocation in response to COVID-19. We proposed the following measures adopted by an Egyptian IVF clinic to support the best practice and face the highly dynamic situation on day to day basis. This could provide guidance for low-resource countries that must cope with the pandemic for an extended period.

- Triaging women based on their symptoms (fever, cough) by phone call carried out by a medical intern prior to the scheduled visit to the ART center. For the new patients first seen in the center, triage is

\footnotetext{
* Correspondence: bmr90@hotmail.com

'Department of Obstetrics \& Gynecology, Faculty of Medicine, Assiut University, Assiut, Egypt

${ }^{3}$ Women Health Hospital, Assiut 71511, Egypt

Full list of author information is available at the end of the article
}

performed before access to the clinic for consultation by a medical intern wearing the appropriate personal protective equipment (PPE).

- Ensuring proper social distancing through proper respect of the time of scheduled visits with spacing out the appointment intervals between patients to minimize the crowding in the waiting area.

Additionally, preventing any relative to the couple to enter the IVF center, especially children or adults over the age of 60 years.

- Laboratory evaluation of all patients before initiating the IVF cycle treatment through complete blood picture, C-reactive protein, erythrocyte sedimentation rate, and serum ferritin [4]. Those with suspicious results are excluded from initiating any cycle treatment. Given the limited data on when COVID19 can be represented by blood level changes of the investigation mentioned above, we advise to repeat them once again on the day of ovulation trigger.

- Patients under immune suppression therapy and those who have medical disorders affecting the immune system are advised to postpone the IVF cycle treatment as the risk of acquiring the COVID19 complications is high.

- Patients sign a written consent before starting the IVF cycle treatment, including the freeze-all embryos policy and deferring the transfer after the pandemic ends. Otherwise, if the couple insisted on fresh embryo transfer, we inform them that the available data on the effect of COVID-19 on pregnancy is limited [5].

- Using the fixed GnRH antagonist protocol and $\mathrm{GnRH}$ agonist triggering for all patients at risk of ovarian hyperstimulation syndrome (OHSS).
Springer Open (c) The Author(s). 2020 Open Access This article is licensed under a Creative Commons Attribution 4.0 International License, which permits use, sharing, adaptation, distribution and reproduction in any medium or format, as long as you give appropriate credit to the original author(s) and the source, provide a link to the Creative Commons licence, and indicate if changes were made. The images or other third party material in this article are included in the article's Creative Commons licence, unless indicated otherwise in a credit line to the material. If material is not included in the article's Creative Commons licence and your intended use is not permitted by statutory regulation or exceeds the permitted use, you will need to obtain permission directly from the copyright holder. To view a copy of this licence, visit http://creativecommons.org/licenses/by/4.0/. 
- Minimizing the monitoring visits by using the longacting GnRH agonist drugs and long-acting gonadotropin stimulation drugs like corifollitropin alfa prefilled pin [6]. Additionally, we encourage the patients for self-administration of IVF medications at home to minimize contact with external personnel [7].

- The use of effective preoperative analgesia in patients requiring office hysteroscopy prior to IVF [8], and the use of paracervical block during the oocyte pick up to minimize the impact of anesthesia on respiratory function. Additionally, the use of airway intervention during general anesthesia leads to aerosol generation, which potentiates the risk of COVID-19 transmission to the surgical team [9].

- Patients who get pregnancy tested for B-HCG through providing a home blood sample by a laboratory technician and repeat it after $48 \mathrm{~h}$ to confirm doubling. Using Telehealth-based care through the Whatsapp messenger, follow-up of their condition and revising the medications in the first eight weeks at home is instituted.

As it is unclear how long the COVID-19 pandemic will continue, we are hoping that those measures could help the ART centers to provide their services for patients in developing countries, especially with low COVID-19 infection rates like Egypt. Moreover, the provided measures could be initially recommended in the centers located in countries with high infection rates such as the European Union and the USA after eradication of the COVID-19 pandemic.

\section{Abbreviations}

ART: Assisted reproductive technology; COVID-19: Coronavirus disease-2019; IVF: In vitro fertilization; OHSS: Ovarian hyperstimulation syndrome;

PPE: Personal protective equipment

\section{Acknowledgements}

Not applicable.

\section{Authors' contributions}

TAF and AMA contributed substantially to the conception and design of the article. MF revised the findings of the work. TAF and AMA wrote the manuscript. MF reviewed and critically revised the article before submission for spelling and grammar. All authors discussed the results and contributed to the final manuscript and provided final approval of the version to publish.

\section{Funding}

None.

Availability of data and materials

Not applicable.

Ethics approval and consent to participate

Not applicable.

Consent for publication

Not applicable.

\section{Competing interests}

The authors declare that they have no conflict of interest.

\section{Author details}

${ }^{1}$ Department of Obstetrics \& Gynecology, Faculty of Medicine, Assiut University, Assiut, Egypt. 'IVF Laboratory, IbnSina IVF Center, IbnSina Hospital, Sohag, Egypt. ${ }^{3}$ Women Health Hospital, Assiut 71511, Egypt.

Received: 11 June 2020 Accepted: 8 September 2020

Published online: 17 September 2020

\section{References}

1. Huang C, Wang Y, Li X, Ren L, Zhao J, Hu Y et al (2020) Clinical features of patients infected with 2019 novel coronavirus in Wuhan, China. Lancet. 395(10223):497-506

2. Wang C, Horby PW, Hayden FG et al (2020) A novel coronavirus outbreak of global health concern. Lancet. 395(10223):470-473

3. Cucinotta D, Vanelli M (2020) WHO declares COVID-19 a pandemic. Acta Biomed 91(1):157

4. Lippi G, Plebani M (2020) Laboratory abnormalities in patients with COVID2019 infection. Clin Chem Lab Med. https://doi.org/10.1515/cclm-2020-0198 [Epub ahead of print]

5. Liang H, Acharya G (2020) Novel corona virus disease (COVID-19) in pregnancy: what clinical recommendations to follow. Acta Obstet Gynecol Scand 99(4):439-432

6. Somkuti SG, Schertz JC, Moore M, Ferrande L, Kelly E, Prefilled GF, Pen in Ol Study 24785 Group (2006) Patient experience with follitropin alfa prefilled pen versus previously used injectable gonadotropins for ovulation induction in oligoanovulatory women. Curr Med Res Opin 22(10):1981-1996

7. Farghaly T, Abbas A, Badran E, Ali MK (2018) The impact of administration of in vitro fertilization medications at assisted reproduction center by nurses versus self-administration at home on patient satisfaction: a cohort study. Fertil Steril 110(4):e156

8. Abbas AM, Elzargha AM, Ahmed AG, Mohamed II, Altraigey A, Abdelbadee AY (2019) Oral diclofenac potassium versus hyoscine-N-butyl bromide in reducing pain perception during office hysteroscopy: a randomized doubleblind placebo-controlled trial. J Minim Invasive Gynecol 26(4):709-716

9. Uppal V, Sondekoppam RV, Lobo CA, Kolli S. Practice recommendations on neuraxial anesthesia and peripheral nerve blocks during the COVID-19 pandemic. Available at https://www.asra.com/page/2905/practicerecommendations-on-neuraxial-anesthesia-and-peripheral-nerve-blocks-dur. Accessed on 10 June 2020.

\section{Publisher's Note}

Springer Nature remains neutral with regard to jurisdictional claims in published maps and institutional affiliations.

\section{Submit your manuscript to a SpringerOpen ${ }^{\circ}$ journal and benefit from:}

- Convenient online submission

- Rigorous peer review

- Open access: articles freely available online

High visibility within the field

Retaining the copyright to your article

Submit your next manuscript at $>$ springeropen.com 